\title{
Effect of Fermentation on Some Minerals and Antinutrient Content of Telfaira Occidentalis and Gnetum Africanum Leaves
}

\author{
*Okolo Ijeoma ${ }^{1}$ and Owolabi Olumuyiwa Adeyemi ${ }^{2}$ \\ ${ }^{1-2}$ Department of Biochemistry, Ahmadu Bello University, \\ Zaria, Kaduna State
}

Nigeria.

\begin{abstract}
Antinutrients are natural compounds in plant foods that interfare with the absorption of nutrients, thereby reducing there their bioavailability. Hence, the need to curb their effect in order to prevent deficiencies of micronutrients becomes paramount. This study therefore aimed at determining the effect of fermentation on some minerals and antinutrients content of Telfaira occidentalis and Gnetum africanum leaves. The vegetables were fermented in the open using deionized water. T. occidentalis and G. africanum leaves were fermented for 24 and 48 hours respectively. Mineral and antinutrient contents were determined using standard methods. The results showed that $\mathrm{Fe}, \mathrm{Zn}, \mathrm{Ca}, \mathrm{Cu}$ and $\mathrm{Mg}$ content were significantly $(p<0.05)$ higher in $\mathrm{T}$. occidentalis than $\mathrm{G}$. africanum, and fermentation significantly $(p<0.05)$ increased the level of $\mathrm{Zn}, \mathrm{Ca}$, and $\mathrm{Cu}$ of both vegetable leaves, while iron (Fe) significantly $(p<0.05)$ increased and Mg significantly $(p<0.05)$ decreased in T. occidentalis, Fe significantly $(p<0.05)$ decreased with Mg showing no significant ( $p>0.05$ ) change in G. africanum. The antinutrient content of phytate and oxalate is significantly $(p<0.05)$ higher in $G$. africanum and fermentation significantly $(p<0.05)$ decreased these antinutrients in both vegetables. The study shows that fermentation significantly $(p<0.05)$ increased the level of $\mathrm{Zn}, \mathrm{Ca}$ and $\mathrm{Cu}$, and significantly $(p<0.05)$ decreased the phytate and oxalate content of both vegetables.
\end{abstract}

Keywords: Vegetables, Fermentation, Antinutrients, Minerals.

\subsection{INTRODUCTION}

Fermentation is one of the oldest and most economical methods of food production and preservation [1]. It is a process by which bacteria, yeasts and moulds convert sugars and carbohydrates into less complex products such as carbon dioxide and alcohol [2]. It involves the conversion of large molecules to small molecules or molecular oxidation/ reduction mechanisms mediated by selected microorganisms [3] Some studies have demonstrated that fermentation of legumes enhances their nutritive value and antioxidant properties; reduces some anti-nutritional endogenous compounds such as phytic acid, and exerts beneficial effects on protein digestibility and biological value $[4,1]$

Telfairia occidentalis is a member of the family Cucurbitaceae commonly known as the fluted gourd, fluted pumpkin or ugwu which is widely cultivated in Nigeria. It has been reported to contain nutrients such as proteins, carbohydrates, vitamins, minerals and fiber. It also contains oxalates, saponins, glycosides, flavonoids, alkaloids and resins [5]. Its medicinal properties includes; antianeamic [6], antidiaebetic, hepatoprotective [7], and a purgative leafy vegetable [8].

Gnetum africanum is a dioecious plant belonging to the family Gnetaceae. It is a non-woody, wild vegetable that grows on trees and is commonly known in southeastern Nigeria as "Okazi" by the Igbo, and "Afang" by the Efik/Ibiobio. It is an important source of protein, essential amino acids and mineral elements [9]. Medicinally, it is used to treat nausea, sore throat and enlarged spleen and also used as a cathartic and as a poison antidote [10].

Leafy vegetables are commonly consumed especially when in season for their micronutrients and medicinal properties, however, they also contain antinutrients which interfare with the absorption of these nutrients. Application of fermentation technique has been shown to decrease the antinutrient content in some food products, but not much report is found in regards to leafy vegetables. 
Therefore this research focused on determining the effect of fermentation on some minerals and antinutrient content of Telfaira occidentalis and Gnetum africanum leaves.

\subsection{MATERIALS AND METHODS}

\subsection{Collection and Identification of Plant Materials}

The matured vegetables (Telfaira occidentalis and Gnetum africanum) were purchased from Sabon gari market in Zaria. The vegetables were authenticated at the Herbarium, Department of Biological Sciences, Ahmadu Bello University, Zaria and a voucher number deposited, 23089 and 1259 for Telfaira occidentalis and Gnetum africanum leaves respectively.

\subsection{Preparation of Plants}

The harvested vegetables were washed, and divided into two parts, one part was air dried at room temperature and then grinded and the other part was fermented. Open fermentation was done, the vegetables were soaked in deionized water for 24 hours for $T$. occidentalis and 48 hours for G.africanum at room temperature for the inherent fermenting microorganisms and environmental fermenting microorganisms to act. The fermented vegetables was then be filtered out and oven dried, then grinded.

\subsection{Determination of Mineral Content}

Plant samples were digested using the method of [11]

$\mathrm{Fe}, \mathrm{Ca}, \mathrm{Cu}, \mathrm{Mg}$ and $\mathrm{Zn}$ content of both leaves and their fermented derivatives was determined using the Atomic absorption spectrophotometry (AAS) method.

\subsection{Determination of Phytate Content}

Phytate content in both leaves was determined using the method of [12]

\subsection{Determination of Oxalate Content}

Oxalate content in both leaves was determined using the method of [13]

\subsection{Determination of Phytate-Fe and Phytate-Zn Molar Ratios}

The molar ratios of phytate to $\mathrm{Fe}$ and phytate to $\mathrm{Zn}$ in both vegetables and their fermented variants was calculated using the method of [14]

\subsection{Statistical analysis}

Results are presented as mean \pm standard deviation except where otherwise stated. Data was analysed using statistical package for the social sciences (SPSS), version 20. Analysis of variance (ANOVA) was used to compare the means. The difference between the various means were compared using the Duncan Multiple Range Test. P values less than $0.05(p<0.05)$ were taken as significant.

\subsection{RESULTS}

\subsection{Mineral Content of Fermented and Unfermented Telfaira occidentalis and Gnetum africanum Leaves}

The mineral content in unfermented and fermented Telfaira occidentalis, and Gnetum africanum leaves is shown in Table 1. Telfaira occidentalis shows significant $(\mathrm{p}<0.05)$ higher content of $\mathrm{Fe}, \mathrm{Ca}, \mathrm{Cu}, \mathrm{Zn}$ and $\mathrm{Mg}$ than Gnetum Africanum leaves. Fermentation significantly $(\mathrm{p}<0.05)$ increased the level of $\mathrm{Zn}, \mathrm{Ca}$, and $\mathrm{Cu}$ of both vegetable leaves. Iron (Fe) significantly $(p<0.05)$ increased while Mg significantly $(\mathrm{p}<0.05)$ decreased in Telfaira Occidentalis. In Gnetum Africanum, the level of Fe significantly $(\mathrm{p}<0.05)$ decreased while $\mathrm{Mg}$ shows no significant $(\mathrm{p}>0.05)$ increase. 
International Journal of Advances in Scientific Research and Engineering (ijasre), Vol 6 (2), February-2020

Table 1: Some Mineral Content of Fermented and Unfermented Telfaira Occidentalis and Gnetum Africanum Leaves

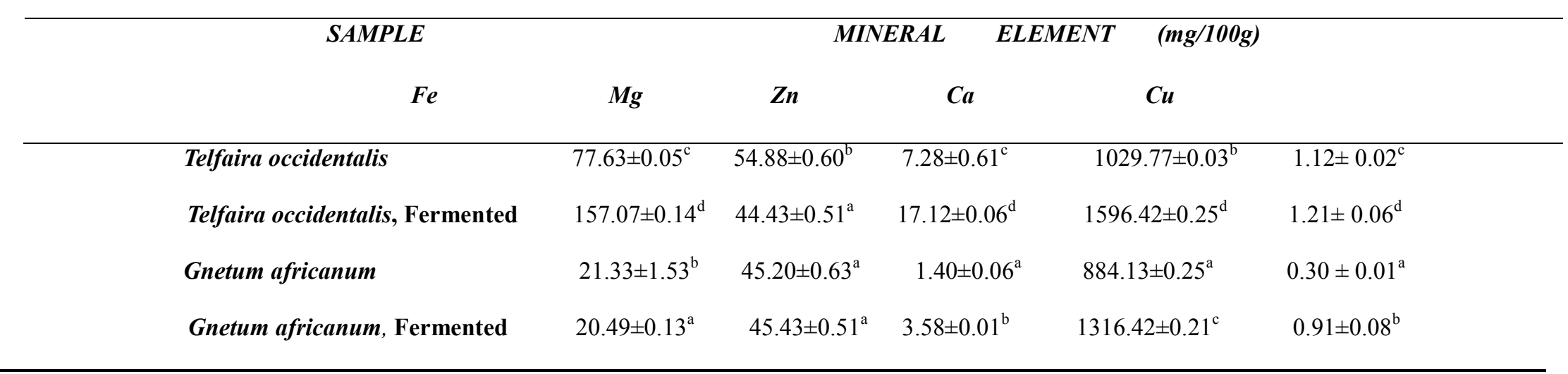

Values are mean \pm S.D of three determinations. Values with different superscript down the column differ significantly $(\mathrm{p}<0.05)$ 


\subsection{Some antinutrient content of Fermented and Unfermented Telfaira occidentalis and Gnetum africanum Leaves}

Antinutrients content of unfermented and fermented Telfaira occidentalis, and Gnetum africanum leaves is presented in Figure 1 and 2. Gnetum africanum shows significant $(\mathrm{p}<0.05)$ higher levels of phytate and oxalate. There was a significant $(\mathrm{p}<0.05)$ reduction in the levels of phytate and oxalate for both vegetables after fermentation.

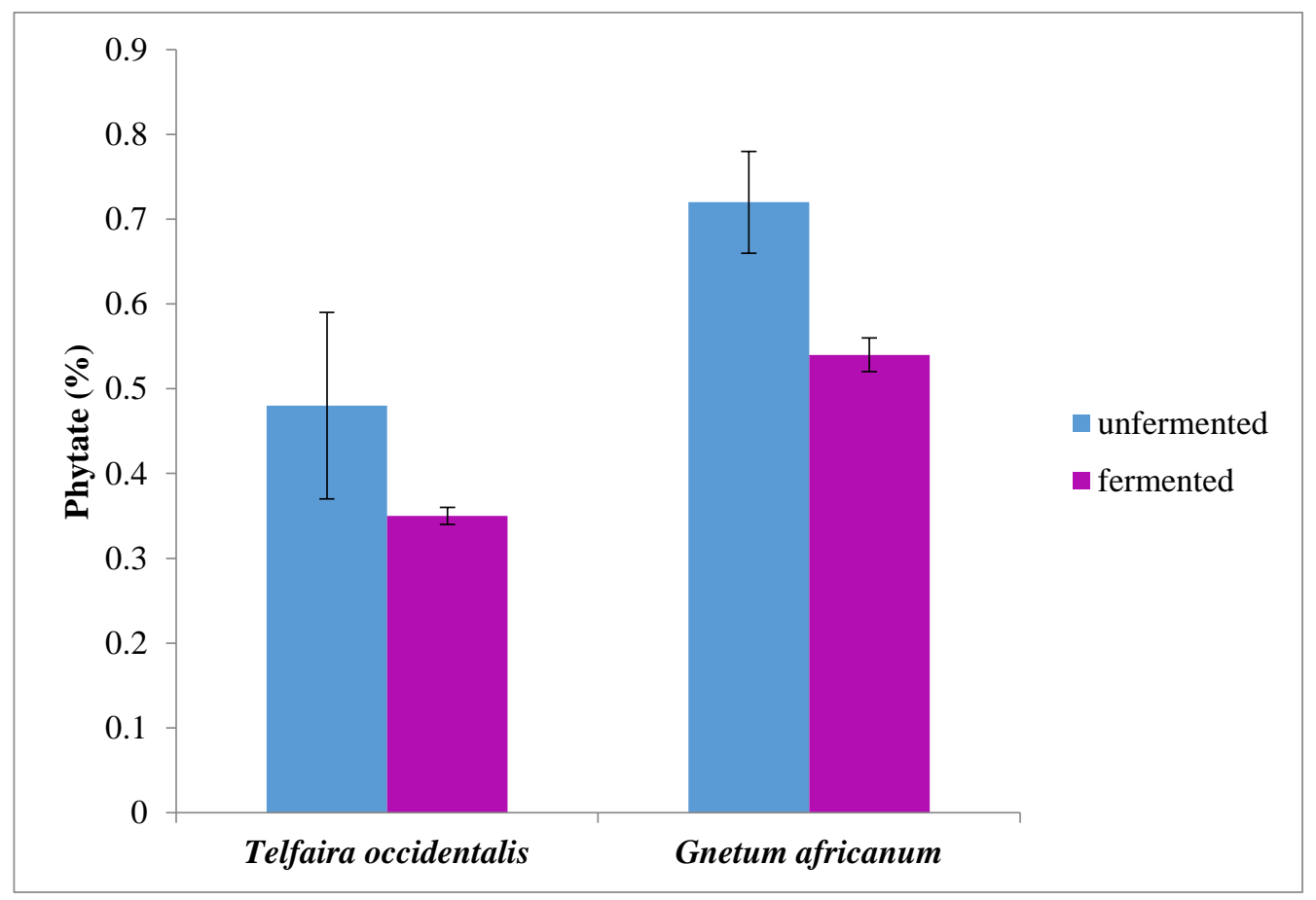

Figure 1. Phytate Content of Fermented and Unfermented Telfaira occidentalis and Gnetum africanum Leaves

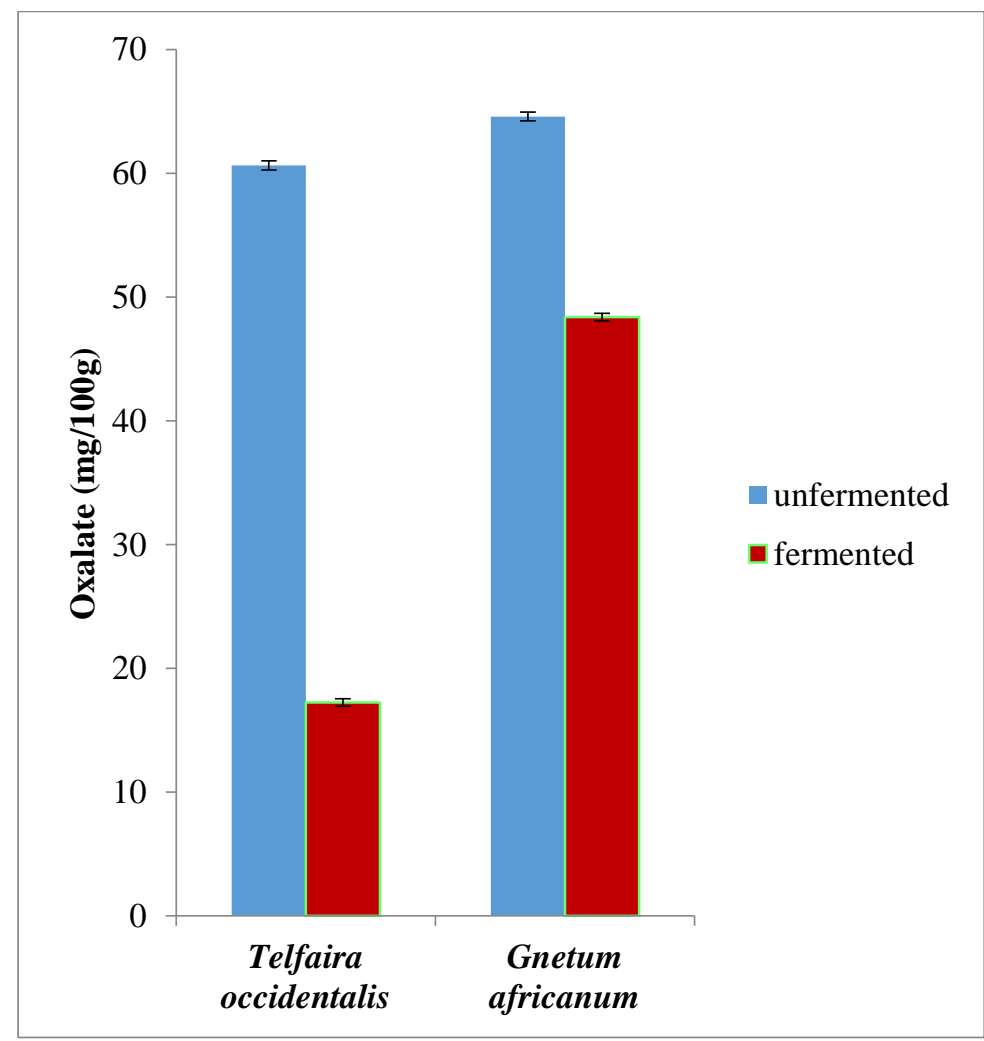

Figure 2: Oxalate Content of Fermented and Unfermented Telfaira occidentalis and Gnetum africanum Leaves 
International Journal of Advances in Scientific Research and Engineering (ijasre), Vol 6 (2), February-2020

\subsection{Molar ratios of phytate:Fe and phytate:Zn in Fermented and Unfermented Telfaira occidentalis and Gnetum africanum Leaves}

The molar ratios of phytate:Fe and phytate:Zn in Fermented and Unfermented Telfaira occidentalis and Gnetum africanum Leaves is shown in Table 2. Molar ratios for phytate-Fe and phytate-Zn were lower in T.occidentalis than G.africanum leaves. These ratios decreased in both leaves after fermentation.

Table 2: Molar Ratios of Phytate:Fe and Phytate:Zn in fermented and Unfermented Telfaira occidentalis and Gnetum africanum leaves

\begin{tabular}{lll}
\hline Samples & Phytate:Fe & Phytate:Zn \\
\hline T.occidentalis, unfermented & 0.52 & 6.50 \\
T.occidentalis, fermented & 0.19 & 2.03 \\
G.africanum, unfermented & 2.85 & 50.97 \\
G.africanum, fermented & 2.20 & 14.95 \\
\hline
\end{tabular}

\subsection{DISCUSSION}

Minerals, classified as micronutrients are needed in small amounts. Deficiency in minerals, however, can have a major impact on health such as anemia and osteoporosis that commonly occur in both developed and developing countries [14] This study focused only on iron $(\mathrm{Fe})$, zinc $(\mathrm{Zn})$, copper $(\mathrm{Cu})$, magnesium $(\mathrm{Mg})$ and calcium $(\mathrm{Ca})$.

Mineral contents were significantly $(\mathrm{p}<0.05)$ higher in T. occidentalis than G.africanum leaf. This is probably because of the differences in botanical structure, as well as in the mineral composition of the soil in which the plants are cultivated. Other factors responsible for a variation in elemental content are preferential absorbability of the plant, use of fertilizers, irrigation water and climatological conditions $[15,16]$. The major minerals analyzed were $\mathrm{Ca}$ and $\mathrm{Mg}$, these are required in amounts greater than $100 \mathrm{mg}$ per day $[17,18]$. Calcium is essential for healthy bones, teeth and blood $[19,20,16]$. The health of the muscles and nerves depends on calcium. It is required for the absorption of dietary vitamin B, for the synthesis of the neurotransmitter acetylcholine, for the activation of enzymes such as the pancreatic lypase. It helps to regulate the activity of skeletal muscle, heart and many other tissues. Deficiency of calcium causes rickets, osteomalacia and scurvy. The recommended dietary allowance of $\mathrm{Ca}$ for children is between 500 and $1000 \mathrm{mg}$ and $800 \mathrm{mg}$ for adults [16]. Hence, both vegetables and their fermented variants can be used to combat Ca deficiency.

Magnesium $(\mathrm{Mg})$ is a major mineral which is required for energy production, oxidative phosphorylation, and glycolysis. It contributes to the structural development of bone and is required for the synthesis of DNA, RNA, and the antioxidant glutathione. It also plays a role in the active transport of calcium and potassium ions across cell membranes, a process that is important to nerve impulse conduction, muscle contraction, and normal heart rhythm [21]. The recommended dietary allowance is $400-420 \mathrm{mg}$ in adult males and $310-320 \mathrm{mg}$ in adult females [22]. Both vegetables and there fermented derivatives are not rich sources of $\mathrm{Mg}$ since their contents are far below the recommended values.

The minor minerals analysed were $\mathrm{Cu}, \mathrm{Zn}$ and $\mathrm{Fe}$ these are required in amounts less than 100mg per day [17, 18]. Copper has the main role in immune system, connective tissue and skeleton, blood formation, the blood vessels and nervous system. Zinc and copper are cofactors of the antioxidant enzyme, superoxide dismutase $(\mathrm{Cu} / \mathrm{Zn}$-SOD) which detoxifies the toxic superoxide radical $[23,24]$. The daily dietary requirement for $\mathrm{Cu}$ is $0.9 \mathrm{mg}$ in adults, $1 \mathrm{mg}$ and $1.2 \mathrm{mg}$ in pregnant and lactating women respectively [25]. T.occidentalis leaves contain higher $\mathrm{Cu}$ contents which was significantly $(\mathrm{p}<0.05)$ higher than the 
International Journal of Advances in Scientific Research and Engineering (ijasre), Vol 6 (2), February-2020

requirement for adults, however the unfermented form meets the requirement during pregnancy and the fermented form meets the requirement for lactating women. The $\mathrm{Cu}$ content of G.africanum leaf is not a rich source of copper since its content is significantly $(\mathrm{p}<0.05)$ lower than the $\mathrm{Cu}$ requirement for adults however, its fermented variant can be used as a rich source of copper. Zinc is necessary for the growth and multiplication of cells (enzymes responsible for DNA and RNA synthesis), for skin integrity, bone metabolism and functioning of taste and eyesight [26]. Zinc deficiency is characterized by recurrent infections, lack of immunity and poor growth. Growth retardation, male hypogonadism, skin changes, poor appetite and mental lethargy are some of the manifestations of chronically zinc-deficient human subjects [27]. The requirement for zinc is $1 \mathrm{mg} / \mathrm{day}$ in infancy; $10 \mathrm{mg} /$ day between 1 and 10 years of age, and $15 \mathrm{mg} /$ day in adults. Pregnant and lactating women require 20 to 25 $\mathrm{mg}$, while normal adults require $15 \mathrm{mg}$ of zinc every day [16]. The unfermented variant of both plants could only meet the $\mathrm{Zn}$ requirement in infancy, fermentation significantly $(\mathrm{p}<0.05)$ increased the $\mathrm{Zn}$ content in both leaves, however, the increase in G.africanum did not meet the requirement for children and adults but that of $T$. occidentalis met the requirement, hence fermented T. occidentalis can be used to combat Zn deficiency.

Iron is an essential component of haemoglobin [28] and myoglobin [29]. It is necessary for growth, development, normal functioning and synthesis of some hormones and connective tissues [30, 29]. Its deficiency ranges from iron depletion to iron deficiency anaemia which affects numerous organs and systems [31]. Recommended intakes for children 4-8yrs is $10 \mathrm{mg}, 14-$ $18 \mathrm{yrs}$ is $11 \mathrm{mg}$ (male), $15 \mathrm{mg}$ (female), for adults $19-50 \mathrm{yrs}$ is $8 \mathrm{mg}$ (males), $18 \mathrm{mg}$ (females), for those that are $51 \mathrm{yrs}$ and above is $8 \mathrm{mg}$ for both males and females [25]. Therefore, the Fe content of these vegetables and there fermented derivatives are good Fe sources.

$\mathrm{Fe}$ and $\mathrm{Zn}$ deficiencies are widespread among people in developing and developed countries [32]. Phytate to Fe molar ratio gives an index of satisfactory Fe absorbtion which should be less than 1 [33]. Similarly, phytate to Zn molar ratios greater than 15 is associated with $\mathrm{Zn}$ deficiency. The Phytate to Fe molar ratio was 0.52 and 0.19 in unfermented and fermented T.occidentalis leaves, 2.85 and 2.20 in unfermented and fermented G.africanum leaves. This shows that the level of phytate in T.occidentalis leaves was not high enough to impair Fe absorption but was high in G.africanum leaves, hence it might not meet up with dietary Fe requirements, this molar ratio can further be reduced by increasing the fermentation time of G.africanum leaf so as to increase the bioavailability of its Fe content.

The phytate Zn molar ratio was 6.50 and 2.03 in unfermented and fermented T.occidentalis leaves, and 50.97 and 14.95 in unfermented and fermented G.africanum leaves. This reveal that the $\mathrm{Zn}$ content in T.occidentalis leaves can meet up with dietary requirements probably because the phytate content was not high enough to impair $\mathrm{Zn}$ availability. The ratio was much higher in unfermented G.africanum leaf suggesting that it has higher phytate content, hence the need to increase the fermentation time.

Fermentation increased the iron content of $T$. occidentalis significantly $(\mathrm{p}<0.05)$ whereas it led to significant $(\mathrm{p}<0.05)$ decrease in G.africanum, there was a significant $(\mathrm{p}<0.05)$ decrease in $\mathrm{Mg}$ content of $T$. occidentalis and a non significant ( $>0.05)$ increase in G.africanum. $\mathrm{Zn}, \mathrm{Ca}$ and $\mathrm{Cu}$ increased significantly $(\mathrm{p}<0.05)$ in both vegetables The observed increase might be due to contribution by the fermenting microorganisms since the reduced antinutrients might have led to the release on some of the minerals bound to them, while the decrease might be due to leaching of the minerals into the fermentation medium probably due to the duration of fermentation. Similar changes in mineral content following fermentation were reported [34] where Fe and Zn content increased significantly after Cassia obtusifolia leaf was fermented. However, a significant decrease in the mineral contents of $T$. occidentalis leaves after fermentation for 5days [35], and also a significant decrease in mineral contents of Sorghum bicolor grains after fermentation for 3 days [36], have both been reported.

Antinutrients are chemicals which have been evolved by plants for their own defense, among other biological functions and reduce the maximum utilization of nutrients especially proteins, vitamins, and minerals, thus preventing optimal exploitation of the nutrients present in a food and decreasing the nutritive value [37].

Phytate, which is also known as inositolhexakisphosphate, is a phosphorus containing compound that binds with minerals and inhibits mineral absorption. The presence of phytate in foods has been associated with reduced mineral absorption due to the structure of phyate which has high density of negatively charged phosphate groups which form very stable complexes with 
International Journal of Advances in Scientific Research and Engineering (ijasre), Vol 6 (2), February-2020

mineral ions such as $\mathrm{Zn}^{2+}, \mathrm{Fe}^{2+/ 3+}, \mathrm{Ca}^{2+}, \mathrm{Mg}^{2+}, \mathrm{Mn}^{2+}$, and $\mathrm{Cu}^{2+}$ causing non-availability for intestinal absorption [38]. They are generally found in food high in fibre especially in wheat bran, whole grains and legumes [39]. Phytate is hydrolysed via intermediate myo-inositolphosphates $\left(\mathrm{InsP}_{5}\right.$ to $\left.\mathrm{InsP}_{1}\right)$ into myo-inositol and inorganic phosphate. Degradation of phytate can be achieved during food processing through the addition of exogenous phytases [40], by micro-organisms producing phytase or by endogenous cereal phytases [41]. Oxalate is an anti-nutrient which under normal conditions is confined to separate compartments. However, when it is digested, it comes into contact with the nutrients in the gastrointestinal tract [42] and binds with minerals, such as $\mathrm{Ca}^{2+}, \mathrm{Fe}^{2+}$, and $\mathrm{Mg}^{2+}$ rendering these minerals unavailable to the body.

The content of phytate and oxalate were significantly higher in G.africanum leaf than T. occidentalis leaf this is probably because phosphorus which is stored as phytate might be higher in G.africanum leaf and maybe there is a greater need for Ca regulation, protection against herbivory and plant survival in G.africanum leaf hence more oxalate was produced [43, 44]. There was a significant reduction in the antinutrient content of both vegetables after fermentation. The loss in phytic acid during fermentation was possibly due to the action of fermenting microorganisms which release phytase to hydrolyze phytate into inositol and orthophosphate [45]. Similar reduction level of phytic acid after fermentation was observed for fluted pumpkin seed and breadfruit seeds, respectively [46, 47]. Significant $(\mathrm{p}<0.05)$ reduction in phytate after fermentation of Cassia obtusifolia leaves were also reported [34]. The significant reduction in oxalate might be due to degradation by the fermenting micro-organisms, [48] which made them leach out of the vegetables due to the acidic medium created during fermentation.

\subsection{CONCLUSION}

This study has shown that fermentation significantly $(\mathrm{p}<0.05)$ increased the $\mathrm{Zn}, \mathrm{Ca}$ and $\mathrm{Cu}$, and significantly $(\mathrm{p}<0.05)$ decreased the phytate and oxalate content in both vegetables.

\section{CONFLICT OF INTEREST}

The authors declare no conflict of interest

\section{ACKNOWLEGEMENT}

The authors acknowledge Dr Musa Bashir of the Multi-User Laboratory, department of chemistry, Faculty of Physical Science, Ahmadu Bello University, Zaria-Nigeria for his assistance during the laboratory work.

\section{REFERENCES}

1. O.A Oyewole, P. Isah. Locally fermented foods in Nigeria and their significance to national economy: A review. Int. J. Recent Adv. Agric. sci. vol.1:pp. 92-102, 2012

2. C.F William, and C.W Dennis. Food Microbiology, $4^{\text {th }}$ ed. McGraw Hill, India, 2011 pp. 330.

3. H. Yadav, S. Jain, R. Rastamanesh, A. Bomba, R. Catanzaro, and Marotta F. Fermentation technology in the development of functional foods for human health: Where we should head. J. Ferment. Tech. vol.1:pp.1-2, 2011

4. G. Oboh, A. Ademosun, and L. Olajide. Improvement of the nutritive value and antioxidant properties of citrus peels through Saccharomyces cerevisae solid substrate fermentation for utilization in livestock feed. Livest. Res. Rural. Dev. Vol. 24:pp. 913,2012

5. E.E.J Iweala, and O. Obidoa. Some Biochemical, haematological and Histological response to a long term consumption of Telfaira occidentalis supplemented diet in rats. Pak. J. Nutr. vol.8: pp.1199-1203, 2009

6. M.F Olaniyan, and A.A Adeleke. Study of the effect of pumpkin (Telfaira occidentalis) milk and raw egg mixture in the treatment of anaemic pregnant women in rural area. Afri. J. Trad. Complem. and Alt. Med. vol.2: pp. 269-273, 2005

7. A. E Olorunfemi, C.I Arnold, O. Emmanuel, N. Nkaima, and A. Akeem. Hypoglycaemic activity of Telfaira occidentalis in rats. J. Pharm. Biores. vol. 2:pp. 36-42, 2005

8. G. Oboh. Hepatoprotective property of ethanolic and aqueous extract of fluted pumpkin (Telfaira occidentalis) in rats. J. Pharm. Biores. vol.2:pp. 36-42, 2006

9. H.G Baker. Plant and Civilization. Macmillan: London, 1972, pp.110

10.H. N Burkill. The useful Plants of West Tropical Africa, $2^{\text {nd }}$ Ed Kew, Royal Botanic Gardens publication, 1985, pp. $456-596$.

11. A. O Majolagbe, V. Kuteyi, C.T Onwordi, and K.A Yusuf. Concentration and Bioavailability of Iron in Some Selected BloodBuilding Medicinal Plants in Southwest Nigeria. J. Environ. vol 2(1), pp.19-24, 2013 
International Journal of Advances in Scientific Research and Engineering (ijasre), Vol 6 (2), February-2020

12. G.M Lucas, and Markakas (1975). Phytic acid and other phosphorus compounds of bean (Phaseolus vulgaris) J. Agr. Educ. Chem. vol.23: pp.13-15, 1975

13. J.R.A Day, and A.L Underwood (1986). Quantitative Analysis $5^{\text {th }}$ Ed., Prentice-Hall publications, London, 1986, pp. 701.

14. M.E Norhaizan, and A.A.W NorFaizadatul (2009). Determination of Phytate, Iron, Zinc, Calcium Contents and their Molar Ratios in Commonly Consumed Raw and Prepared Food in Malaysia. Malays. J. Nutr. vol.15(2), pp. 213 - 222

15. N.S Rajurkar, and B.M Pardeshi. Analysis of Some Herbal Plants from India Used in the Control of Diabetes Mellitus by NAA and AAS Techniques. Appl. Radiat. Is. vol. 48(8), pp. 1059-1062, 1997

16. R. Lokhande, P. Singare, and M. Andhale, (2010). Study on Mineral content of Some Ayurvedic Indian Medicinal Plants by Instrumental Neutron Activation Analysis and AAS Techniques. Health. Sci. J. vol.4(3), pp. 157-168, 2010

17. B. Imelouane, M. Tahri, M. Elbastriou, F. Aouinti, and A. Elbachiri. Mineral contents of some medicinal and aromatic plants growing in Eastern Morocco. J. chem. soc. Pak. vol.33, pp. 260-262, 2011

18. A.T.J, Ogunkunle O.S Bello, and A.F Ogundola. Ascorbic acid and mineral elements composition of powdered antimalarial (Maloff-HB) and haematinic (Haematol-B) herbal formulations from Ogbomoso, Nigeria. Afri. J. Biotech. vol. 13(24), pp. 2466-2473, 2014

19. M.N Hughes. The Inorganic Chemistry of Biological Processes. Wiley, London, 1972, pp 334

20. P. Charles. Calcium absorption and calcium bioavailability. J. Intern. Med. vol. 231(2), pp. 161-165, 1992

21. R.K Rude. Magnesium. In: Modern Nutrition in Health and Disease. $11^{\text {th }}$ ed. A.C Ross, B. Caballero, R.J Cousins, K.L Tucker, T.R Ziegler (Eds). Baltimore, Mass: Lippincott Williams and Wilkins, 2012, pp. 159-175.

22. Institute of Medicine (IOM). Food and Nutrition Board. Dietary Reference Intakes: Calcium, Phosphorus, Magnesium, Vitamin D and Fluoride. Washington, DC: National Academy Press, 1997

23. A.O Çavdar, E. Unal, E. Babacan, S. Gozdaşoglu, G. Yavuz, and K. Mengubaş. Trace element analysis (zinc and selenium) in pediatric malignant lymphomas. Turk. J. Haematol. vol.19, pp. 239-244, 2002

24. C.A Ross, C.L Taylor, A. L Yaktine, and H.B Del Valle. DRI dietary reference intakes, calcium, vitamin D. The National Academies Press, Washington, D.C., USA,2011

25. Institute of Medicine (2001). Dietary reference intakes for vitamin A, vitamin K, arsenic, boron, chromium, copper, iodine, iron, manganese, molybdenum, nickel, silicon, vanadium, and zinc. The National Academies Press, Washington, D.C., USA (2001)

26. L. Thunus, and R.Lejeune. Handbook on Metals in Clinical and Analytical Chemistry. Marcel Dekker, New York, 1994

27. A.S Prasad (1982).Clinical, Biochemical and Nutritional Aspects of Trace Elements. Alan R. Liss, Inc, New York. pp. 5-15

28. M. Wesssling-Resnick. Iron. In: Modern nutrition in health and disease. $11^{\text {th }}$ ed. A.C. Ross, B. Caballero, R.J Cousins, K.LTucker and R.G Ziegler (Eds). Baltimore, MD: Lippincott Williams and Wilkins, 2014, pp. 176-188

29. P.J Angett. Iron. In: Present knowledge in nutrition. $10^{\text {th }}$ ed. J.W Erdman, I.A Macdonald, and S.H Zeisel (Eds). Washington DC: Wiley-Blackwell, 2012, pp. 506-520

30. L.E Murray-Kolbe, and J. Beard (2010). Iron. In: Encyclopedia of dietary supplements. $2^{\text {nd }}$ ed. P.M Coates, M.R Blackman (Eds). London and Newyork: Informa Healthcare, 2010, pp. 432-438

31.P. Joshi, and B. Mathur. An evaluation of iron deficiency and effect of leaf concentrate supplementation on haemoglobin levels of adult rats. J. herb. med. toxicol. vol.3(2), pp. 133-136, 2009

32. T.H Tulchinsky. Micronutrient deficiency conditions;Global health issues. Pub. Health. Rev. vol.32, pp. 243-255, 2010

33. M.B. Reddy, and J.D Cook. Assessment of dietary determinants of nonheme-iron absorption in humans and rats. Am. J. Clin. Nutr. vol.54(4), pp. 723-728, 1991

34. M.O Nuha, A.M.A Isam, and E.B Elfadil. Chemical composition, antinutrients and extractable minerals of Sicklepod (Cassia obtusifolia) leaves as influenced by fermentation and cooking. Int. Food. Res. J. vol.17, pp. 775-785, 2010

35. B.O.T Ifesan, O.O Egbewole, and B.T Ifesan. Effect of Fermentation on Nutritional Composition of Selected Commonly Consumed Green Leafy Vegetables in Nigeria. Int. J. Appl. Sci. Biotech. vol.2(3), pp. 291-297, 2014

36. M.B Raihanatu, S. Modu, A.S Falmata, Y.A Shettima, and M. Heman. Effect of processing (sprouting and fermentation) of five local varieties of sorghum on some biochemical parameters. Biokemistri. vol. 23(2), pp. $91-96,2011$

37. F.G Habtamu, R. Negussie. Antinutritional factors in plant foods: Potential health benefits and adverse effects. Int. J. Nutr. Food. Sci. vol.3(4), pp. 284-289, 2014

38. H.LWalter, L. Fanny, C. Charles, and R.Christia. Minerals and phytic acid interaction: is it a real problem for human nutrition. Int. J. Food. Sci. Tech. vol.37, pp. 727-739, 2002

39. O. Lori, V. Thava, and H.H James. Phytic acid. Food. Rev. Int. vol.17, pp. 419-431, 2001

40. U. Konietzny, and R. Greiner. Molecular and catalytic properties of phytate-degrading enzymes (phytases). Int. J. Food. Sci. Tech. vol. 37(7), pp. 791-812, 2002.

41. R. Greiner, K.D Jany, and A.M Larsson. Identification and Properties of myo -Inositol Hexakisphosphate Phosphohydrolases (Phytases) from Barley (Hordeum vulgare). J. Cereal. Sci. vol.31(2), pp. 127, 2000

42. S.C Noonan, G.P Savage. Oxalic acidand its effects on humans. Asia. pac. J. Clin. Nutr. 8, pp. 64-74, 1999.

43. V.R Franceschi, and P.A Nakata. Calcium oxalate n plants: formatin and function. Annu. Rev. Plant. Biol. Vol. 5, pp.41-71, 2005 
International Journal of Advances in Scientific Research and Engineering (ijasre), Vol 6 (2), February-2020

44. P.A Nakata. Plant calcium oxalate crystal formation, function and its impact on human health. Front. Biol. vol.7(3, pp. 254266, 2012

45. A.S Sandberg, and T. Andlid. Phytogenic and microbial phytases in human nutrition. Int. J. Food. Sci. Tech. vol. 37:pp. 823, 2002

46. S.Y Giami. Effect of fermentation on the seed proteins, nitrogenous constituents, antinutrients and nutritional quality of fluted pumpkin seeds (Telfairia occidentalis). Food Chem. vol. 88, pp. 397-404, 2004

47. F.M Ugwu, and N.A Oranye (2006). Effects of some processing methods on the toxic components of African bread fruit (Treculia africana). Afri. J. Biotech. vol.5, pp. 2329-2333, 2006

48. J.V Madeira Jr,, J.A Macedo, and G.A Macedo. Detoxification of castor bean residues and the simultaneous production of tannase and phytase by solid-state fermentation using Paecilomyces variotii. Biores. Tech. vol.102, pp. 7343-7348, 2011. 